\title{
Application of the Brandis Method for Yield Regulation of Pine Private Forest in Tana Toraja
}

\author{
Hardjanto $^{1^{*}}$, Melewanto Patabang ${ }^{2}$ \\ ${ }^{1}$ Department of Forest Management, Faculty of Forestry, IPB University (Bogor Agricultural University), Dramaga Campus, \\ Bogor, Indonesia 16680 \\ ${ }^{2}$ School of Vocational Studies, IPB University (Bogor Agricultural University), Cilibende Campus, Bogor, Indonesia 16151
}

Received May 6, 2019/Accepted July 15, 2019

\begin{abstract}
The utilization of private forests in Indonesia that is not managed properly based on the principle of sustainable yield will result in the depletion of private forests in the not too distant future. Therefore the sustainability of private forest is a necessity that cannot be delayed anymore. The general objective of this research is to find out whether the yield regulation method (Brandis Method) can be applied in private forests. The specific objectives of this study are: (a) to analyze the characteristics of pine private forests and their suitability for the Brandis Method practice, and $(b)$ to know the sustainability of pine forest products in Tana Toraja using the Brandis Method and its institutions. The data collected in this study consist of primary and secondary data. The analytical method used was descriptive analysis and yield regulation method was analyzed based on Brandis Method. The result of this study shows that the yield regulation of the private pine forests in Tana Toraja can be done based on the number of trees using the Brandis Method. The regulation of private forest products based on the number of trees can be carried out if there is support from privateforest institutions.
\end{abstract}

Keywords: Brandis Method, institution, private forest, sustainable yields, yield regulation

*Correspondence author, email: hardjanto@gmail.com

\section{Introduction}

Private forests according to Government of Indonesia (GOI) Law Number 5/1967 concerning Basic Forestry Provisions are referred to as proprietary forests, namely forests that grow or are planted on property, which are commonly referred to as private forests and can be owned privately, either alone or with other people or entities law (Republik Indonesia, 1967). Whereas according to GOI Law Number 41/1999 concerning Forestry (substitute for Law Number 5/1967) Article 5 Paragraph 1 (b) the term proprietary forest is replaced with the right term of forest in the explanatory chapter namely private forests (Departemen Kehutanan, 1999). According to Awang et al. (2001), Hardjanto (2003), and Hendarto (2003), private forests in Indonesia are land forests that are not controlled by the government, so private forests are forests owned by the people. Private forests in United States according to Stein et al. (2005) are forests that are on private land owned by individuals, families, corporations, groups/organizations, tribes, or the forestry industry. Acharya et al. (2008) suggest that private forests in Nepal are forests on private land that are planted, maintained, and protected in accordance with applicable law. According to Kulkarni et al. (2013), private forests in the western region of Indian Ghast are forests that are on privately owned land and are not used for agricultural land or other non-forestry activities, and this land is overgrown by endemic tree species or the type of rehabilitation activities. However, it was further stated that private forests that are common in Dodamarg and Sawantwadi Talukas from Sindhudurg District (India) owned by all hamlets or villages can also be referred to as private forests. The development of private forest definition has now expanded by de facto towards who the manager is, starting from the ownership of a tree in the yard to hundreds of trees according to the ownership of the land (Hardjanto, 2017). As a business, the tree owner farmers have interacted with various parties, namely timber middlemen, small to large industries, board sellers who are carried up to building materials stores, also tree seed sellers, and other parties (Hardjanto et al., 2013; Hero et al., 2014).

The management of private forest should be carried out separately and different from the management of natural production forest and plantation forest, due to its distinct characteristics. According to Awang (2005), the characteristics of private forest management are individual, informal in management, irresponsive, subsistence, and being savings for families of private forest owners. Furthermore, Widiarti and Prajadinata (2008) suggested that 
the characteristics of private forests include: irregular spacing, number of trees of each type varies, and the number of trees in one species has different age variations. The results of Jariyah and Wahyuningrums' research (2008) show that the characteristics of forests in Java can be divided into three characters, namely (1) private forests that are purely planted with timber, (2) private forests planted with timber and fruit trees, and (3) private forest planted with wood, fruits, and empon-empon. Furthermore, the results of Widiarti and Prajadinatas' study (2008) show that private forests have mixed garden patterns and are still managed traditionally with a vegetation structure that is simpler than the vegetation structure in natural forests, but in terms of tree density and canopy it resemblances to natural forest ecosystems. The results of the research by Sanudin and Fauziyah (2015) show that the characteristics of private forests on subsistence farmers are closer to complex agroforestry models (more diversified species), simple management, and harvesting is mostly done with selective logging systems, while semicommercial or commercial farmers, the characteristics of private forests are closer to simple agroforestry systems (monoculture), intensive management, and harvesting which is mostly done with a clear-cutting system.

According to Acharya et al. (2008), private forests in Nepal can be classified into three types, namely: (1) forests registered as privately owned forests in district or city forestry service offices in all countries, (2) agro-forest, which is privately owned land planted trees used as sources of animal feed, wood, and fruit where trees planted on private land (such as agro forest, not registered as private forests) are similar to land leases, and (3) 'tree ownership' forest system, namely the sharing of profits between owners land with managers who plant trees not on their land. Characteristics of private forests can also be seen from the large of ownership with different square measure and managed on a small scale. Based on the extensive ownership of Best and Wayburn (2001), it was suggested that private forests in the United States range from 1 to more than 1000 ha $(58.52 \%$ of private forest owners range from 1 to 9 ha while, private forests with $\geq 1000$ ha is only owned by $0.27 \%$ of the total ownership). According to Harrison et al. (2002), the scale of ownership of private forests in Europe has a wide ownership starting from 2 ha and can reach 500 ha, while in Japan $90 \%$ of private forests have an area of less than 2 ha. The wide variety of private forests is also found in Tana Toraja with a range of 0.25 to 6 ha and an average area of 1.17 ha (Malamassam, 2007). According to Hardjanto (2017), private forests that grow on land owned by property are generally fragmented, so it is often not easy to do forest management based on their functions.

Private forests in Indonesia with various characteristics must be managed based on sustainable yield principles so that their forest potency does not decrease. According to Davis et al. (2011), sustainable forest management is a management to produce production continuously with the aim of achieving a balance between growth and products every year or a certain period. To achieve sustainable results there are three important requirements that must be met in forest management, namely: the existence of boundaries of forest areas that are still and recognized by the community, the existence of silviculture systems that guarantee the implementation of forest regeneration, and the determination of harvest logging which guarantees the realization of timber products (Simon, 2010). Forest sustainability can be achieved by maintaining a balance between the economic, ecological, and social benefits of forests (Clarck et al., 1997). Sustainability of yield products can also be achieved by controlling the stability of ecosystems and natural disturbances. According to Elbakidze et al., (2013), the determination of forest sustainability is based on three elements, namely the amount of regeneration, the amount of available stock, and the growth rate of trees. The application of silviculture systems to proper and correct maintenance of private forests has a function and role to improve the quality and quantity of production (Lewerissa, 2008). Widayanti (2004) argues that forest sustainability requires continuous yields/production and wherever possible increases both the quality and quantity. Simon (2010) further argues that the sustainability of forest products requires a constant level of production for the intensity of certain forest management, where growth and harvesting must be balanced.

According to Malamassam (2006), based on the conditions of distribution, extent, and proximity of the location, private forest management can be grouped on the private forest management unit, where each of these units can be managed as a sustainable class that continuously supplies wood raw materials for the timber industry. Suhendang (1995) argues that the level of result sustainability that provides the highest benefits will be given by forests that reach normal conditions. Simon (2010) argues that beside based on area, volume, and increment of stands; the appropriate yield regulation methods is very important to achieve sustainable forest management. One method of yield regulation used the number of trees and another is the Brandis Method.

Until now, the application of the Brandis Method to private forest in Indonesia is still rare. According to Karminarsih (2012) the concept of yield regulation that has used valid in private forest management activities in Indonesia is based on the number of trees. Therefore, methods that might be applicable to the yield regulation of private forest can be approached the Brandis Method. It is done because the structure of the private forest stands occur scattered in mixture of the large number of the other tree species. According to Myint (2012), the Brandis Method can be used in forests that have a mixed stand structure. The regulation of forest products is not only useful for limiting the amount of logging that can be carried out at a sustainable level, but also be used further to measure the capability of private forests in terms of the supply of timber needs of the timber industry continuously. van Gardingen et al. (2006) suggest that there is no one model of yield regulation that is suitable for all types of forests if the arrangement is seen from social, ecological, economic, and environmental aspects. The implementation of private forest product management activities needs to be supported by good institutions considering the characteristics of private forests with a small and diverse area and owned by many individuals. According to Karminarsih (2012), one of the things that needs to be formulated in developing a sustainable private forest 
management unit is the establishment of institutions.

The general objective of this research is to find out whether the Brandis method could be used for the yield regulation of private forests. The specific objectives of this study are (1) analyzing the characteristics of pine private forests and their suitability for the application of the Brandis Method, and (2) knowing the sustainability of pine forest products in Tana Toraja using the Brandis Method and its institutions.

\section{Methods}

Study area The ownership status of private forests in the study area based on land ownership consists of two, individual and family owned. The area of ownership varies, based on the results of interviews the ownership of private forest land of respondents ranged from 0.25 to 4 ha. The extent of this ownership in detail is presented in Table 1 and Table 2. In addition to the structure of stands of pine private forests in the study area also shows a variety of age classes. The survey results show that the age class of pine private forests ranges from 5 to more than 30 years. In addition there are also areas in pine private forests that are mixed with other types of plants such as bamboo (Bambuseae sp), sengon (Albizia chinensis), cempaka (Elmerilla ovalis), clove (Syzygium aromaticum), casuarina (Casuarina junghulniana Miq.), etc.

The intensive utilization of pine private forests in study areas has only just begun to be declared since 2002 by the community, which is marked by granting licenses to several

Table 1 Pine (Pinus merkusii) private forests in the study area

\begin{tabular}{|c|c|c|}
\hline Urban village & Area (ha) & Proportion $(\%)$ \\
\hline Rante Kalua & 51.60 & 1.76 \\
\hline Lemo & 312.97 & 10.68 \\
\hline Tampo & 204.16 & 6.97 \\
\hline Tengan & 113.00 & 3.86 \\
\hline Buntu Datu & 28.35 & 0.97 \\
\hline Buntu Tangti & 63.00 & 2.15 \\
\hline Gasing & 121.70 & 4.15 \\
\hline Ke'pe tinoring & 88.00 & 3.00 \\
\hline Marinding & 83.00 & 2.83 \\
\hline Pakala & 102.70 & 3.51 \\
\hline Palipu & 182.50 & 6.23 \\
\hline Pa'tengko & 122.80 & 4.19 \\
\hline Randanan & 37.90 & 1.29 \\
\hline Rantedada & 147.10 & 5.02 \\
\hline Simbuang & 428.10 & 14.62 \\
\hline Uluway & 224.31 & 7.66 \\
\hline West Uluway & 617.96 & 21.10 \\
\hline Total & $2,929.15$ & 100.00 \\
\hline
\end{tabular}

companies. The government has since made a number of restrictions and requirements both in terms of the amount of potential that must be purchased or harvested and in terms of the source or origin of pine wood. The government requires that wood that can be purchased is only limited to timber originating from private forests only. Prior to 2002, continuous logging activities were carried out without being compensated for by replanting. The accessibility of the pine private forest area has been already quite good because most of the area is accessible by four-wheeled vehicles or more. Therefore, so that the efforts to utilization of the pine private forest do not cause a negative impact, efforts are needed to realize forest sustainability.

Data collection The data collected in this study consists of primary and secondary data. Primary data were obtained through measurements, observations, and interviews, to verify secondary data from the results of research by Patabang et al. (2014). These data include age and distribution as well as interviews with private forest farmers and other stakeholders involved in private forest management. Secondary data in this study were obtained through the study of documents and literature which included documents relating to private forests in the form of biophysical conditions and private forest management policies. This research was carried out by purposive sampling method in Mengkendek District, Tana Toraja Regency in the private forest area as presented in Figure 1.

Data analysis Data analysis in this study was carried out by using several approaches, namely descriptive analysis, mean value estimation analysis, analysis for yield regulation using Brandis method, and institutional analysis. Descriptive analysis has been used to explain the history of private forest management which had been implemented in the study area.

\section{Stand volume estimation}

Potential assessments are carried out on private pine forests by analyzing the results of research conducted by Patabang et al. (2008) and Patabang et al. (2014). The used measuring sample plots are $20 \times 20 \mathrm{~m}^{2}$ at each of the sampling location. The selection of measuring sample plots location for every age class in each location was random sampling, where each of the age class was

Table 2 Villages and their pine private forest in study area

\begin{tabular}{lccc}
\hline \multirow{2}{*}{$\begin{array}{c}\text { Village } \\
\text { (lembang) }\end{array}$} & \multicolumn{3}{c}{ Pine private forest area (ha) } \\
\cline { 2 - 4 } Randanan & 0.80 & Maximum & Average \\
Uluway & 1.00 & 2.00 & 1.19 \\
Rantedada & 0.25 & 2.00 & 1.25 \\
Pa'tengko & 0.30 & 4.00 & 1.81 \\
Tampo & 0.40 & 1.00 & 0.58 \\
Palipu & 0.50 & 0.50 & 0.48 \\
Pakala & 0.25 & 0.50 & 0.50 \\
Simbuang & 0.25 & 1.00 & 0.50 \\
\hline Average & 0.47 & 1.00 & 0.55 \\
\hline
\end{tabular}


represented by 30 measuring plots. The measured trees were from 5 to more than 30 years old trees. The overall estimation of private forest stands is carried out using the mean value estimation method (Malamassam, 2012) with the Equation [1].

$$
\frac{1}{\mathrm{~L}}\left(\mathrm{~V}-\mathrm{t} . \mathrm{Sv} \leq \mathrm{Vha}^{-1} \leq \mathrm{V}+\mathrm{t} . \mathrm{Sv}\right) \mathrm{m}^{3}
$$

note: $\mathrm{V}=$ volume $\left(\mathrm{m}^{3}\right) ; \mathrm{L}=$ area of the sample plot (ha); $\mathrm{t} . \mathrm{Sv}=$ margin of error; confident interval $=95 \%$

\section{Yield regulation}

The concept of yield regulation that is valid until now in private forest management activities is based on the number of stems. Therefore, methods that might be applicable to the regulation of private forest products can be approached through the Brandis Method, without ignoring the current management system, in other words must consider the local socio-cultural conditions and the capacity of private forest farmers as manager (Karminarsih, 2012). This method was first developed in Burma by Brandis in 1856 (Osmaston, 1968). The Brandis Method is also known as the Myanmar Selection System (MMS) and began to be developed in forest management in Burma from 1880 to 1920 . The Brandis Method can be applied to forests with different age with a very diverse diameter composition, ranging from small to large diameter that ripe for cutting (Rohman et al., 2014). The Brandis Method can also be applied to forests that have experienced degradation and over-exploitation (Myint, 2012).

In general, to regulate felling based on the tree number method (Osmaston, 1968), some information is needed as follows:

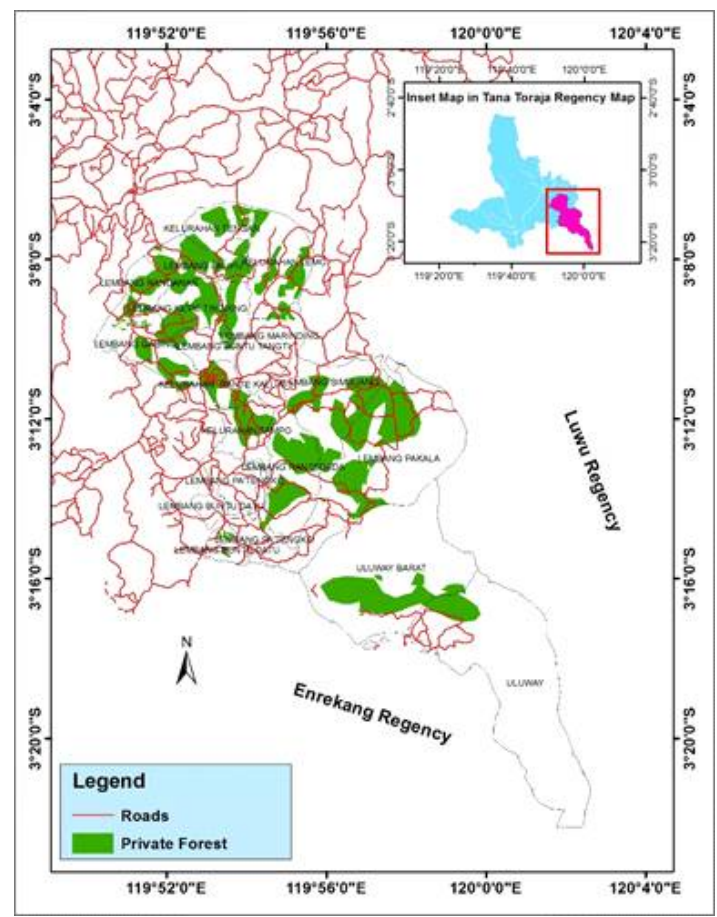

Figure 1 Map of the distribution of private forest in the study area. a. Determination of diameter classes based on inventory results. The diameter class is determined using the Sturges criterion as shown in Equation [2], Equation [3], and Equation [4] (Sudjana, 2005):

$\mathrm{K}=1+3,322 \log \mathrm{n}$

Class interval $=\frac{\text { class range }}{\mathrm{K}}$

class range $=$ data maximum - data minimum note: $\mathrm{K}=$ number of class, $\mathrm{n}=$ number of data

b The number of trees in each size diameter class. For this stage, inventory results in study are grouped by diameter class based on the number of classes that have been made.

c The time of passage, i.e. the times taken by trees to grow through the various size-classes to exploitable size. The time of passage was calculated by using Figure 2 and yield table of pine stand (Patabang et al., 2014) of private forest in study area. So, in general, Figure 2 shows the available stock of class 1 trees as working stock at the start of a cycle, must be recruited half from class 2 during the cycle. The Figure 2 used in the calculation will be the times of passage and the number of trees that will eventually reach exploitable size. From them, calculation of the average rate of recruitment to class 1 and the consequent numbers of working stock (class 1 trees) needed. The Figure 2 used in the calculation will be the time of passage (Table 6, column 5) and number of finally available trees for exploitation (Table 6, column 7) for each age class in the study area. From them are calculated the

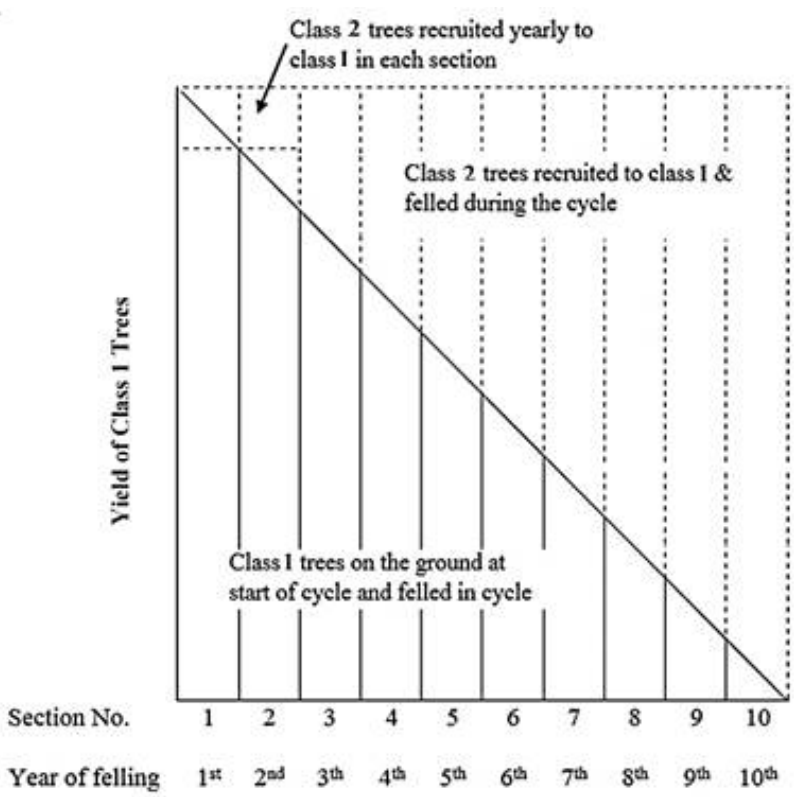

Figure 2 Annual yield of class 1 trees with felling cycle 10 years (Osmaston, 1968). 
average rate recruitment to class 1 and the consequent number of working stock (class 1 trees) needed. The time of passage for each age class in the study area using Figure 2 showed of yield table of study area (Patabang et al., 2014) i.e. 30 years for class 6, 25 years for class 5 , and 20 years for class 3 and 4 .

d The casualty percent (CPC) of each size class, i.e. the per cent on the number of each class that die, are blown over or the thinned before they reach exploitable size. The number of trees in each diameter class from the inventory results will be estimated how many percent reached class 1 which will then be cut down. For this study diameter classes were based on grouping according to stand age obtained from the yield table of study area. The principle of applying casualty per cent in the Brandis Method is the belief that not all small diameter trees that grow in the forest will survive reaching the size of ripe tree diameter (Rohman et al., 2013). The CPC calculating with Equation [5].

$\mathrm{CPC}=\frac{\mathrm{T}}{\mathrm{N}}$

note: $\mathrm{T}=$ remaining stand potential/final felling (trees number ha $\left.{ }^{-1}\right) ; \mathrm{N}=$ number of trees $\left(\mathrm{ha}^{-1}\right)$.

The casualty per cent will used in this study i.e. diameter class $4-6$ are $16 \%$, diameter class 3 are $18 \%$, diameter class 2 are $25 \%$, and diameter class 1 are $39 \%$.

e The annual allowable cut (AAC) in study area calculated used Brandis Method is as shown in Equation [6], Equation [7], Equation [8], Equation [9], Equation [10], Equation [11], and Equation [12]:

$\mathrm{A}_{\mathrm{i}}=\mathrm{N}_{\mathrm{i}}-\left(\mathrm{N}_{\mathrm{i}} \times \mathrm{CPC}_{\mathrm{i}}\right)$

$\mathrm{D}_{\mathrm{i}(\mathrm{t}=1)}=\mathrm{A}_{\mathrm{i}}$

Diameter Class 2-6:

$\mathrm{D}_{\mathrm{it}}=\mathrm{D}_{(\mathrm{i}-1)(\mathrm{t}-1)}-\left(\mathrm{D}_{(\mathrm{i}-1)(\mathrm{t}-1)} \times \mathrm{CPC}_{\mathrm{i}}\right)$

$\mathrm{C}_{\mathrm{t}}=\mathrm{T}_{\mathrm{t}}+\mathrm{S}_{\mathrm{t}-1}$

$\mathrm{AAC}_{\mathrm{t}}=\frac{\mathrm{C}_{\mathrm{t}}}{\mathrm{R}}$

$\mathrm{S}_{\mathrm{t}}=\mathrm{C}_{\mathrm{t}}-\mathrm{AAC}_{\mathrm{t}}$

Diameter class 1

$D_{t}=A A C_{t}$

note: $\mathrm{N}=$ number of trees $\left(\mathrm{ha}^{-1}\right) ; \mathrm{A}=$ number of finally available trees for exploitation $\left(\mathrm{ha}^{-1}\right) ; \mathrm{D}=$ number of trees on diameter class $\left(\mathrm{ha}^{-1}\right) ; \mathrm{CPC}=$ casualty per cent (\%); AAC = annual allowable cuts $\left(\right.$ ha $^{-1}$ years $\left.{ }^{-1}\right) ; \mathrm{C}=$ number of tree can be cut (years ${ }^{-1}$ ); $\mathrm{R}=$ cutting cycle/rotation (years); $\mathrm{S}=$ residual stand $\left(\mathrm{ha}^{-1}\right) ; \mathrm{i}=$ diameter class $(1,2,3,4,5) ; \mathrm{t}=$ years $(2,3,4,5,6,7,8$, $9,10)$.

\section{Institutional analysis}

Institutional analysis is carried out using a discourse approach. Data analysis using this approach was carried out to analyze the current process of making private forest management policies. According to Hardjanto et al., (2012), the approach to analysis of this discourse is closely related to the use of science in determining the policies and behavior of actors and networks of cooperation and interests. The research approach and analysis of institutional discourse were used as approaches in institutional studies (Arts \& Buizer, 2009; Hawitt 2009).

\section{Results and Discussion}

The history of private forest in Tana Toraja The results of surveys and interviews with stakeholders related to private forests in the study area indicate that social life of Toraja people have always been governed by a number of norms or rules. These rules include mana' which is a system that regulates the ownership of inheritance. In Toraja community, concept mana' is inherited property and it is often considered sacred and needs to be stored or maintained properly. The same principle applies to mana' in the form of rice fields or land and forests which are the responsibility of that Tongkonan (traditional house), where Tongkonan also has function as a center for managing the life of Toraja indigenous people. In mana' system in Toraja a plot of land can be inherited to children and grandchildren which is usually shared after participating in certain ceremonies. Besides sharing inheritance, there is also land that is not shared but still belongs to Tongkonan. Generally, Tongkonan has customary forest, besides being a source of wood for building materials, customary forest can also be a source of medicinal ingredients for Tongkonan members.

The land in the form of mana' is planted with bamboo (Bambuseae sp), casuarina (Casuarina junghulniana Miq.), and cempaka (Elmerilla ovalis) by the Toraja community, where the harvest results are used as materials for building tongkonan or huts for traditional ceremonies. Currently, $m a n a^{\prime}$ is used as the basis for land ownership in Tana Toraja. In the relations of Toraja community, it is clearly seen the values, rules, and norms that are needed to develop in an effort to foster, rehabilitate, conserve, and utilize existing natural resources. Some examples of customary rules in various Toraja community activities related to the management and use of private forests are presented in Table 3. Since the issuance of Law Number 5/1967 concerning the Basic Provisions of Forestry, the land belonging to the Tongkonan and private property of inheritance in Tana Toraja is known as the name of private forest.

This private forest in Tana Toraja has become a supplier of various local wood needs, including to meet the needs of the construction of traditional houses, the material of which $100 \%$ is consisting of wood and bamboo (Malamassam, 2005). The survey results and interviews with smallholding forest farmers can be seen that pine in Tana Toraja began to be planted since the late 1960s through community self-help and through a greening assistance program. In the framework of utilizing pine plants in Tana Toraja Regency, the Governor of South Sulawesi Province in 1994 issued a Decree Number 71/II/1994 dated October 12, 1994 concerning Technical Guidelines for Maintenance of Timber and Resin Products from the Pine Private Forest in Tana Toraja. The maintenance activities intended are thinning and wiretapping, but there is 
Table 3 Some examples of rules in Toraja community activities

\begin{tabular}{lll}
\hline Activity & \multicolumn{1}{c}{ Rule/customary law } & Executive/person in charge \\
\hline Cutting down trees & Must be permitted by a customary institution & Tomina (Customary leader) \\
and burning forest & Perform special ceremonies & Tomina (Customary leader) \\
& Must be done in certain types of trees & Tomina (Customary leader) \\
& Must be conducted in amount as needed & Tongkonan \\
& Must be within customary territory & Tongkonan \\
& Not allowed in wellspring area & Tongkonan \\
\hline Cultivating the land & Own land/customary land & Tongkonan \\
& Making a terrace on sloping land & Tongkonan \\
& Not allowed to harm others & Tongkonan \\
& Should not be on the river bank or cliff edge & Tongkonan \\
\hline Building a house & Wood and building materials come from their & Tomina (Customary leader) \\
& own community/customary forest & Tongkonan \\
& Using certain types of wood & Tongkonan \\
\hline Raising livestock & Collecting livestock manure for crop fertilizer & Tongkonan \\
\hline
\end{tabular}

no further explanation of how thinning and tapping are carried out. According to Malamassam (2006), the use of pine plants in Tana Toraja, among others, is driven by two things as follows (1) the increase of limitation of timber raw materials from natural forests on the one hand, and the progress in the field of wood technology that can increase economic value and use value of softwood (including pine), to other parties, and (2) the economic increase in pine wood, followed by an increase in demand for timber from private forests, especially pine forests, to supply the needs of the pine wood industry which had been considered unable to provide significant economic benefits to their owners, turned into a source of funds to meet various interests.

The utilization of pine forests in the Tana Toraja was begun to declare in 2002 by the community and the Tana Toraja Government, which was marked by granting permits to several companies to manage pine private forests with a number of restrictions and requirements.

Stand volume potency The results of the potential estimation analysis using the middle value estimation method for the study area are presented in Table 4 . The results of the analysis in Table 4 show that the average volume of pine private forest trees aged 5 to 30 years ranges from $245.28 \mathrm{~m}^{3}$ ha ${ }^{-1}$ to $299.27 \mathrm{~m}^{3} \mathrm{ha}^{-1}$ with an average margin of error 1.08 , indicating that the estimated error is quite small, namely $19.43 \%$. Calculation of the stand volume potency is based on the stand volume table of pine private forests in Patabang et al. (2014) and primary data from the inventory of stands aged 5 to 30 years

Based on the analysis results, it can also be obtained the potential of pine stand in each area in the study area as in Table 5. The results of data analysis in Table 5 are based on the effective area of $75 \%$ private forest of pine trees overgrown in 20 years and above. The data in Table 5 shows that the biggest potentcy of pine stand is in Lembang Uluway West, which is $97.119 .30 \mathrm{~m}^{3}$ and the smallest is in Lembang Ke'pe 'Tinoring which is only $2.534 .65 \mathrm{~m}^{3}$ of the total potency in the study area. The potency of pine private forest is quite large but if it is not managed properly, especially yield regulation, it is estimated that in a relatively short time the private forest will be exhausted.

Application of the Brandis Method Forest yield regulation is the planning and implementation in a forest management, by considering the technical aspects of forestry, environmental aspects and economic financial aspects. The emphasis in forest yield regulation is the work of yield collection, while other work (planting and protecting) is a series of activities after harvesting. For private forests, this regulation is very important to maintain continuity of production because generally logging in private forests is depend on the financial needs of the owners, who generally do not pay attention to the continuity of production. Due to the condition of private forests that are specific in terms of these characteristics, so the yield regulation methods that can be applied must also be specific.

As a first step in the Brandis Method, an annual cuts calculation of the all study area was carried out with assuming that all private forests in the study area were in one management unit/yield regulation. Overall for the all study area annual cuts calculated using a 20-year cycle based on stand volume tables (Patabang et al., 2014). The results of the Brandis Method analysis in the study area are presented in Table 6 and Table 7.

Yield regulation on this study based on Table 6 uses several assumptions that are adjusted to the conditions of the study area. Data on pine stands from the field inventory were divided into six groups based on diameter classes with intervals of each class of $6 \mathrm{~cm}$. The annual felling is calculated based on the number of trees that are ready to be harvested, trees that have reached a diameter of $31 \mathrm{~cm}$ or more. Calculation of annual felling is carried out using a 20 year cycle with diameter increment of $1.57 \mathrm{~cm}$ year $^{-1}$ (Patabang et al., 2014). This diameter increment is in the range of site class 2 and site class 3 according to Suharlan et 
Table 4 Estimation of stand volume potency in study area

\begin{tabular}{|c|c|c|c|c|c|c|}
\hline \multirow[t]{2}{*}{$\begin{array}{l}\text { Age } \\
\text { (year) }\end{array}$} & \multirow[t]{2}{*}{$\begin{array}{l}\text { Average volume } \\
\left(\mathrm{m}^{3} \text { plots }^{-1}\right)\end{array}$} & \multirow[t]{2}{*}{$\begin{array}{l}\text { Margin } \\
\text { of error }\end{array}$} & \multicolumn{2}{|c|}{$\begin{array}{c}\text { Volume } \\
\text { estimation } \\
\left(\mathrm{m}^{3} \text { plots }^{-1}\right)\end{array}$} & \multicolumn{2}{|c|}{$\begin{array}{l}\text { Volume estimation } \\
\qquad\left(\mathrm{m}^{3} \mathrm{ha}^{-1}\right)\end{array}$} \\
\hline & & & Min. & Max. & Min. & Max. \\
\hline 5 & 0.87 & 0.06 & 0.81 & 0.93 & 20.25 & 23.25 \\
\hline 10 & 7.08 & 0.49 & 6.59 & 7.57 & 164.75 & 189.25 \\
\hline 15 & 9.36 & 0.81 & 8.55 & 10.17 & 213.75 & 254.25 \\
\hline 20 & 12.19 & 1.04 & 11.15 & 13.24 & 278.67 & 330.89 \\
\hline 25 & 17.23 & 1.67 & 15.56 & 18.91 & 388.97 & 472.67 \\
\hline 30 & 18.61 & 2.40 & 16.21 & 21.01 & 405.26 & 525.32 \\
\hline Average & 10.89 & 1.08 & 9.81 & 11.97 & 245.28 & 299.27 \\
\hline
\end{tabular}

Table 5 Estimation of volume in the effective area

\begin{tabular}{lrrr}
\hline Village (Lembang) & $\begin{array}{r}\text { Area } \\
\text { (ha) }\end{array}$ & $\begin{array}{r}\text { Effective } \\
\text { area (ha) }\end{array}$ & $\begin{array}{c}\text { Volume } \\
\left(\mathrm{m}^{3}\right)\end{array}$ \\
\hline Buntu Datu & 28.35 & 21.26 & $4,252.50$ \\
Buntu Tangti & 63.01 & 47.25 & $9,450.98$ \\
Gasing & 121.65 & 91.24 & $18,248.00$ \\
Ke'pe' Tinoring & 88.00 & 66.00 & $13,200.00$ \\
Lemo & 312.97 & 234.73 & $46,945.50$ \\
Marinding & 83.20 & 62.40 & $12,480.26$ \\
Pakala & 102.69 & 77.02 & $15,403.20$ \\
Palipu & 182.48 & 136.86 & $27,372.54$ \\
Patengko & 122.77 & 92.08 & $18,416.16$ \\
Randanan & 37.96 & 28.47 & $5,694.00$ \\
Rantedada & 147.88 & 110.91 & $22,181.92$ \\
Rantekalua & 51.63 & 38.72 & $7,744.28$ \\
Simbuang & 428.11 & 321.08 & $64,216.99$ \\
Tampo & 204.16 & 153.12 & $30,624.00$ \\
Tengan & 113.00 & 84.75 & $16,950.00$ \\
West Uluway & 617.96 & 463.47 & $92,694.00$ \\
East Uluway & 224.31 & 168.23 & $33,646.50$ \\
\hline \multicolumn{1}{c}{ Total } & $2,930.14$ & $2,197.60$ & $439,520.82$ \\
\hline
\end{tabular}

al., (1975) i.e. $1.46 \mathrm{~cm}_{\text {years }}{ }^{-1}$ (site class 2) and $1.62 \mathrm{~cm} \mathrm{years}^{-1}$ (site class 3). Based on the results of the data analysis in Table 6 , it can be known that among the trees in the diameter class 6 , i.e. 5\% (17 trees) will die before reaching the age of finally available trees for exploitation. For diameter class 1, a number of 39\% (641 trees) will reach the age of finally available trees for exploitation and $61 \%$ will die before harvesting due to thinning or natural influences. The number of the age of finally available trees for exploitation with diameter class 6 is 333 trees while the number of trees that can be cut from diameter class 1 to diameter class 5 is 2.197 trees.

The number of trees with diameter class 1 can be distinguished by time of passage ( 95 trees) and for one cutting cycle (20 years). The rate of growth of new trees for one time of passage is 23 trees and the rate of growth of new trees for one cutting cycle is 20 trees $\mathrm{ha}^{-1}$. The results of the logging calculation are based on the data in Table 6 based on one time of passage. The number of tree supplies needed is 232 trees and the excess stock of trees is 104 trees. If the excess trees in the diameter class 6 will be cut in 2 (two) cutting cycles, the annual cut will be 25 trees. Based on this description, it can be made to determine the annual cutting allowance for yield regulation in pine forests in the study area as presented in Table 6.

The results of data analysis for the Brandis Method in Table 6 and Table 7 were obtained after analyzing the primary data and stand volume table of the study area from the previous research (Patabang et al., 2014). Based on the results of data analysis in Table 7, it can be seen that the first annual cut for the first cycle is 20 trees ha ${ }^{-1}$, however total annual cutting will change in subsequent years until the stands form a normal forest. According to Karminarsih (2012), the application of yield regulation based on increment and number of trees for the first five year period is considered as 
Table 6 Pine growing stock in a felling series (cutting cycle $=20$ years)

\begin{tabular}{|c|c|c|c|c|c|c|}
\hline Class & $\begin{array}{l}\text { Diameter } \\
(\mathrm{cm})\end{array}$ & $\begin{array}{c}\text { Number of trees } \\
\left(\text { No. of trees years }{ }^{-1}\right)\end{array}$ & $\begin{array}{c}\text { Average age of } \\
\text { lower limit of class } \\
\text { (years) }\end{array}$ & $\begin{array}{c}\text { The time passage } \\
\text { (years) }\end{array}$ & $\begin{array}{l}\text { The casualty } \\
\text { percent }(\%)\end{array}$ & $\begin{array}{c}\text { No. of trees finally } \\
\text { available for } \\
\text { exploitation } \\
\left(\text { years }^{-1}\right)\end{array}$ \\
\hline (1) & (2) & (3) & (4) & (5) & (6) & (7) \\
\hline 1 & $<7$ & 1,050 & 5 & - & 39 & 641 \\
\hline 2 & $7-12$ & 658 & 10 & - & 25 & 493 \\
\hline 3 & $13-18$ & 470 & 15 & 20 & 18 & 384 \\
\hline 4 & $19-24$ & 410 & 20 & 20 & 16 & 344 \\
\hline 5 & $25-30$ & 397 & 25 & 25 & 16 & 335 \\
\hline 6 & $\geq 31$ & 395 & 30 & 30 & 16 & 333 \\
\hline \multicolumn{2}{|c|}{ Total } & 3,380 & 105 & 95 & & 2,550 \\
\hline
\end{tabular}

Tabel 7 Determination of annual harvesting (annual cut) in study area

\begin{tabular}{|c|c|c|c|c|c|c|c|c|c|c|}
\hline \multirow{2}{*}{ Year } & \multicolumn{6}{|c|}{$\begin{array}{l}\text { The number of trees per class of diameter }(\mathrm{cm}) \\
\qquad\left(\mathrm{ha}^{-1}\right)\end{array}$} & \multirow{2}{*}{$\begin{array}{c}\text { C } \\
\text { (No. of } \\
\text { tree }{ }^{\text {ha-1 }} \text { ) }\end{array}$} & \multirow{2}{*}{$\begin{array}{c}\text { Annual cut } \\
\text { (No. of tree } \\
\mathrm{ha}^{-1} \text { ) }\end{array}$} & \multirow{2}{*}{$\begin{array}{l}\text { Residue stand } \\
\text { (No. of tree } \\
\text { ha }^{-1} \text { ) }\end{array}$} & \multirow[t]{2}{*}{ Planting } \\
\hline & 1 & 2 & 3 & 4 & 5 & 6 & & & & \\
\hline 1 & 1,050 & 658 & 470 & 410 & 397 & 395 & 395 & 20 & 375 & 20 \\
\hline 2 & 35 & 641 & 494 & 385 & 344 & 333 & 709 & 35 & 673 & 35 \\
\hline 3 & 48 & 22 & 480 & 405 & 324 & 289 & 963 & 48 & 914 & 48 \\
\hline 4 & 59 & 29 & 16 & 394 & 340 & 272 & 1186 & 59 & 1127 & 59 \\
\hline 5 & 71 & 36 & 22 & 13 & 331 & 286 & 1413 & 71 & 1342 & 71 \\
\hline 6 & 81 & 43 & 27 & 18 & 11 & 278 & 1620 & 81 & 1539 & 81 \\
\hline 7 & 77 & 49 & 32 & 22 & 15 & 9 & 1548 & 77 & 1471 & 77 \\
\hline 8 & 74 & 47 & 37 & 26 & 19 & 13 & 1484 & 74 & 1409 & 74 \\
\hline 9 & 71 & 45 & 35 & 30 & 22 & 16 & 1425 & 71 & 1354 & 71 \\
\hline 10 & 69 & 43 & 34 & 29 & 26 & 19 & 1373 & 69 & 1304 & 69 \\
\hline
\end{tabular}

the period of adjustment. The next five-year harvest has shown a relatively stable of annual cut, where the number of trees felled increases compared to the first five-year cut. When logging has been completed, then replanting a greater amount of cutting to realize the sustainability of the results is done, it can be expected that the annual production will be greater. The results of this study shown that the annual allowable cut can be applied well if the location of the pine private forests is located on a wide expanse of land.

Based on the survey results it is known that the pine private forests are spread in several regions, but still occupy quite large areas greater than 1 ha, as owned by several individuals/farmers. In order to overcome this problem, it is necessary to arrange the area to regulate logging. Alternative systems that can be used to manage the logging area are establishing forest management institutions at the lembang (village) level. This institution is also expected to improve the bargaining position of farmers in selling their forest products and increasing farmers' knowledge of forest management technology based on the concept of sustainable management.
Supporting institution The GOI Law Number 41/1999 states that "private forests are forests that are burdened by property both individually and collectively or in groups (custom)". The private forests have characteristics that are different from production natural forests and plantation forests, thus private forest management, especially regarding yield regulation, must be carried out in a separate method. The characteristics mentioned above require a specific yield regulation system in accordance with the conditions of each private forest. To support the regulatory system that has been stated previously, a special institution is needed. This institution is expected to be able to regulate the selling value of timber and the logging system based on the determined level. This institution must involve farmers or private forest owners, local governments and forest industries in using private forest products as well as universities or research institutions. This management institution is expected to be able to act as a manager and facilitator in regulating private forest products and other activity in private forest management. The linkages between these institutions can be described as shown in Figure 3. 
Particularly for private forestry components, it needs good regulation so that these activities can be carried out by paying attention and ensuring a balance between socioeconomic and environmental protection interests. Specific characteristics of private forests, especially in terms of patterns of ownership require the need for a management organization that can support and facilitate regulatory activities that guarantee the balance of interests intended above. Institutions for yield regulation of private forest are needed to play a role as organizers and facilitators in determining logging location and logging quota. So that, no logging is carried out carelessly based solely on the owners' wishes without regard to the negative impacts caused especially environmental impacts. In addition, institutions at the farm level are also expected to be able to help private forest management activities, which include counseling and technical guidance or the provision of production and marketing facilities. The existence of these institutions is expected to further guarantee the implementation of more

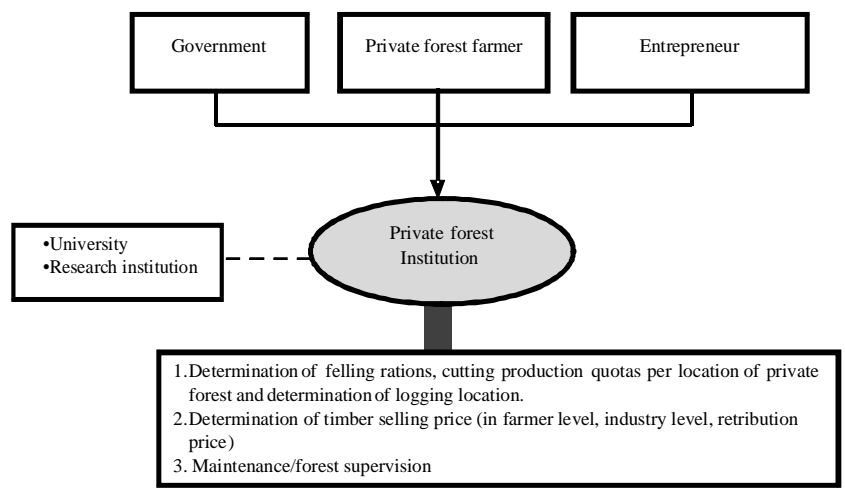

Figure 3 Institution scheme of private forest management. integrated and directed private forest management activities, and at the same time it can be expected to play a role in supporting the development and improvement of the potential of private forests.

The system mentioned above can be made into an organizational system as shown in Figure 3. In order to be implemented properly, these farmer groups should be formed in each lembang/village as the smallest government unit. The part of the organizational structure which is expected to play a more important role is the part of cultivation and marketing because these two parts are needed by farmers to manage their private forests sustainably. The farmer group can be optimal if the duties of each member are clearly specified, so that the coordination and implementation of tasks will run well. According to Hardjanto et al. (2012), the institutional design produced for improving the performance of private forests in order to create forest and forest product sustainability will work well if all actors strive for it consistently. The task plan for each part of the farmer group

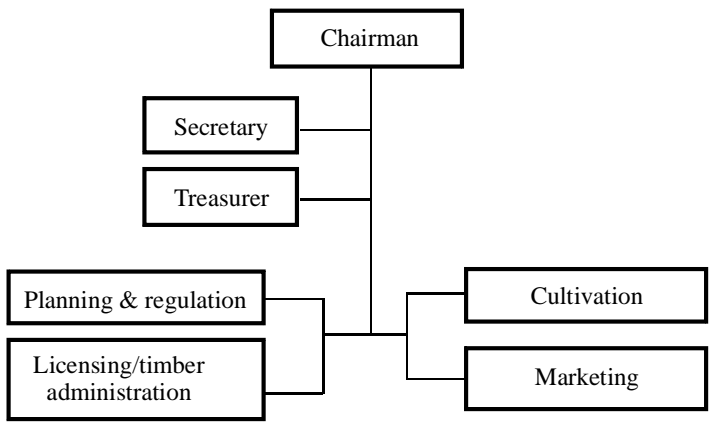

Figure 4 Institutional setting of farmer group in private forest management.

Table 8 Task design for each member of the farmer group

\begin{tabular}{ll}
\hline \multicolumn{1}{c}{ Section } & \multicolumn{1}{c}{ Task } \\
\hline Planning and wood yield & Registratiing the members and the area of land ownership in a management area/yield \\
regulation & regulation \\
& Identifying existing private forest potential \\
& Making production development plan \\
& Making plan for funding activities \\
& Making activity evaluation \\
\hline Licensing/ & Making yield regulation plan \\
Timber administration & Making plan for harvesting techniques \\
& Carrying out timber administration especially logging permit \\
\hline Cultivation & Determining the number and type of plants to be planted \\
& Carrying out cultivation techniques starting from planting, thinning and logging \\
\hline Marketing & Establishing and managing cooperatives and prepare production facilities \\
& Marketing the yield \\
\hline
\end{tabular}


members in Figure 4 in detail is presented in Table 8.

\section{Conclusion}

The yield regulation of private pine forests in Tana Toraja can be done based on the number of trees using the Brandis Method. Based on this method, private pine forests in the study area can be grouped into a ten-year cutting cycle with the annual cut ranging from 20 to 81 trees $^{-1}$. The activity of yield regulation of private forest based on the number of trees can be carried out if there is support from private forest institutions. The yield regulation institutions are needed to play a role as a managers and facilitators in determining logging location and quota. In addition, institutions at the farm level are also expected to be able to help foster private forest management. Private forest institutions consist of three main elements i.e. the government, farmers, and entrepreneurs.

\section{Recommendation}

In order to increase the economic value of private pine forests for farmers in implementing sustainable yield regulation methods it is necessary to establish institutions at farmer level in a broader scale. The institution must be consists of the government, farmers, and entrepreneurs.

\section{References}

Acharya, K. P., Adhikari, J., \& Khanal, D. J. (2008). Forest tenure regimes and their impact on livelihoods in Nepal. Journal of Forest and Livelihood, 7(1) 6-18.

Arts, B., \& Buizer, M. (2009). Forests, discourses, institutions: A discursive-institutional analysis of global forest governance. Journal Forest Policy and Economics, 11(5-6), 340-347. https://doi.org/10.1016/j.forpol. 2008.10.004

Awang, S. A., Santosa, H., Widayanti, W. T., Nugroho, Y., Kustomo, \& Supardiono. (2001). Guratan Hutan hutan Rakyat rakyat di Kapur Selatan. Yogyakarta: Debut Press.

Awang, S. A. (2005). Seri Bunga Rampai Hutan Rakyat. Fakultas Kehutanan Universitas Gajahmada.

Best, C., \& Wayburn, L. A. (2001). America's private forests. Washington: Status and Stewardship. Island Press.

Clarck, J. R., Matheny, N. P., Cross, G., \& Wake, V. (1997). A model of urban forest sustainability. Journal of Arboriculture, 23(1), 17-30.

Davis, L. S., Johnson, K. N., Bettinger, P. S., \& Howard, T. E. (2001). Forest management to sustain ecological, economic and social value. $4^{\text {th }}$ ed. New York: McGrawHill Companies.

Departemen Kehutanan. 1987. Undang-Undang Republik Indonesia No. 5 Tahun 1967 tentang Kehutanan. Jakarta: Departemen Kehutanan.

Departemen Kehutanan. 1999. Undang-Undang Republik
Indonesia No. 41 Tahun 1999 tentang Kehutanan. Jakarta: Departemen Kehutanan.

Elbakidze M, Angelstam P. 2007. Implementing sustainable forest management in Ukraine's Carpathian Mountains: The role of traditional village systems. Forest Ecology and Management 249, 28-38. https://doi.org/10.1016/ j.foreco.2007.04.003

Elbakidze, M., Andersson, K., Angelstam, P., Armstrong, G. W., Axelsson, R., Doyon, F., ... \& Pautov, Y. (2013). Sustained yield forestry in Sweden and Russia: How does it correspond to sustainable forest management policy? Ambio, 42, 160-173. https://doi.org/10.1007/s13280012-0370-6

Hardjanto. (2003). Keragaan dan pengembangan usaha kayu rakyat di Pulau Jawa [dissertation]. Bogor: IPB University.

Hardjanto, Hero, Y., \& Trison, S. (2012). Institutional design on people forest to establish forest and business sustainability in order to poverty alleviation in rural communities. Jurnal Ilmu Pertanian Indonesia, 17(2), 103-107.

Hardjanto, Hero, Y., \& Rahaju, S. (2013). Integrasi produksi dan pengolahan kayu rakyat sebagai solusi pengembangan hutan rakyat. Bogor: Fakultas Kehutanan Institut Pertanian Bogor.

Hardjanto. (2017). Pengelolaan hutan rakyat. Bogor: IPB Press.

Harrison, S., Herbohn, J., \& Niskanen, H. (2002). Nonindustrial, smallholder, small-scale and family forestry: What's in a name? Small-scale Forest Economics, Management and Policy, 1(1), 1-11.

Hawitt, S. (2009). Discourse analysis and public policy research. Discussion Paper Series No. 24. Centre for Rural Economy, Newcastle University.

Hendarto, A. K. (2003). Proyek kehutanan sosial dan penganggaran berwawasan gender: Suatu ulasan teoritis. Jurnal Hutan Rakyat, 5(1), 1-16.

Hero, Y., Hardjanto, \& Rahaju, S. (2014). Model kemitraan usaha hutan rakyat berdasarkan pendekatan kelembagaan. Bogor: Fakultas Kehutanan Institut Pertanian Bogor.

Jariyah, N. A., \& Wahyuningrum, N. (2008). Karakteristik hutan rakyat di Jawa. Jurnal Penelitian Sosial dan Ekonomi Kehutanan, 4(1), 43-46. https://doi.org/10.1016/j.foreco.2007.04.003

Karminarsih, E. (2012). Unit pengelolaan hutan rakyat lestari skala kecil: Kasus di Kecamatan Cikalong, Kabupaten Tasikmalaya, Jawa Barat [dissertation]. Bogor: IPB University. 
Kulkarni, J., Mehta, P., \& Kamble, C. (2013). Study of status, distribution and dynamics of private and community forests in Sahyadri-Konkan corridor of Maharashtra Western Ghats. Technical Report submitted to CEPFATREE. Pune: Wildlife Research and Conservation Society.

Lewerissa, E. (2008). Penerapan silvikultur pada hutan rakyat dengan aplikasi pemeliharaan. Jurnal Agroforestri, 3(1), 47-58.

Malamassam, D. (2005). Pengkajian ulang pemanfaatan dan pengelolaan hutan rakyat di Tana Toraja. Makassar: P3DAS LPPM Unhas.

Malamassam, D. (2006). Management planning of public forest in Tana Toraja Regency. Jurnal Perennial, 2(2), 37-43. https://doi.org/10.24259/perennial.v2i2.159

Malamassam, D. (2007). The contribution of pine community forest to the community income in Tana Toraja Regency. Jurnal Perennial, 3(1), 32-39.

Malamassam, D. (2012). Membedah potensi hutan. Bogor: IPB Press

Myint, T. T. (2012). A study on the sustainable management of natural teak forest in Myanmar. [dissertation]. Tokyo: The University of Tokyo.

Patabang, M., Wijayanto, N., \& Hardjanto. (2008). Strategi pengembangan hutan pinus rakyat di Kabupaten Tana Toraja. Jurnal Manajemen Hutan Tropika, 14(3), 97-103.

Patabang, M., Malamassam, D., \& Hardjanto. (2014). Growth model of pine (Pinus merkusii Jungh. Et de Vriese) stand on community forest in Tana Toraja Regency. Jurnal Manajemen Hutan Tropika, 20(1), 1-8. https://doi.org/10.7226/jtfm.20.1.1

Republik Indonesia. 1967. Undang-Undang Republik Indonesia No. 5 Tahun 1967 tentang Ketentuanketentuan Pokok Kehutanan. Jakarta. https://fkkm.org/2016/09/28/uu-no-5-tahun-1967/.

Rohman, Warsito, S.P., Supriyatno, N., Purwanto, R.H.,
Atmaji C. (2014). Evaluation of annual allowable cut (AAC) determination of teak forest plantations in Perum Perhutani, Indonesia. Jurnal Manajemen Hutan Tropika 20(3), 195-202. https://doi.org/10.7226/jtfm.20.3.195

Sanudin, \& Fauziyah, E. (2015). Karakteristik hutan rakyat berdasarkan orientasi pengelolaannya: Studi kasus di Desa Sukamaju, Ciamis dan Desa Kiarajangkung, Tasikmalaya, Jawa Barat. Prosiding Seminar Nasional Masyarakat Biodiversitas Indonesia, 1(4), 696-701. https://doi.org/10.13057/psnmbi/m010402

Stein, S. M., McRoberts, R. E., Alig, R. J., Nelson, M. D., David, M., Theobald, Eley, M., ... \& Carr, M. (2005). Forests on the edge: Housing development on America's private forests. Pacific Northwest Research Station General Technical Report. U.S. Department of Agriculture Forest Service. https://doi.org/10.2737/ PNW-GTR-636

Sudjana. (2005). Metoda statistika. Edisi ke-6. Bandung: Tarsito

Suharlan, A., Sumarna, K., Sudiono, J. (1975). Tabel tegakan sepuluh jenis kayu industri. Bogor: Pusat Penelitian dan Pengembangan Hutan Bogor.

Suhendang, E. (1995). Ukuran kelestarian hasil dalam pengusahaan hutan alam produksi. Bogor: Fakultas Kehutanan Institut Pertanian Bogor.

van Gardingen P. R., Valle, D., \& Thompson, I. (2006). Evaluation of yield regulation options for primary forest in Tapajo's National Forest, Brazil. Forest Ecology and Management, 231(13), 184-195. https://doi.org/ 10.1016/j.foreco.2006.05.047

Widayanti, T. W. (2004). Implementasi metode pengaturan hasil hutan pada pengelolaan hutan rakyat (Studi di Desa Kedung Keris, Kecamatan Nglipar, Kabupaten Gunung Kidul). Jurnal Hutan Rakyat, 6(2), 27-46.

Widiarti, A., \& Prajadinata, S. (2008). Karakteristik hutan rakyat pola kebun campuran. Jurnal Penelitian Hutan dan Konservasi Alam, 5(2), 145-156. https://doi.org/10.20886/jphka.2008.5.2.145-156 